\title{
THE SYNERGY OF ETHICAL ASPECTS AND STATE DEFENCE CHARACTERS TO ACCOUNTING COMPETENCY
}

\author{
${ }^{1}$ * Gideon Setyo Budiwitjaksono, ${ }^{1}$ Indrawati Yuhertiana, ${ }^{1}$ Luqita Romaisyah \\ ${ }^{1}$ Accounting Department, Faculty of Economic and Business, \\ Universitas Pembangunan Nasional "Veteran" Jawa Timur \\ *Corresponding Author
}

DOI: 10.46609/IJSSER.2020.v05i03.010 URL: https://doi.org/10.46609/IJSSER.2020.v05i03.010

\section{ABSTRACT}

This study aims to explain empirically about the synergy of ethical aspects, the character of state defence and accounting competence in the accounting profession society. The study uses qualitative research, with an interpretive approach. Data collected in-depth interviewed and active observation. There are several accounting profession communities, with members who work as public accountants, tax accountants, management accountants and educator accountants, in several cities in Java, including Surabaya, Semarang, Yogyakarta, Bandung, Jakarta. The result of this study showed that accountants are professions that carry out their work always prioritizing aspects of controlled behaviour based on a code of ethics regulated in their profession.

Moreover, accountants also carry out their work following scientific abilities and technical expertise. Professional accountants show evidence in their competency. There are several components, namely; specialized knowledge that demands continuous and consistent expertise or skills and experience; very high moral standards; serve the interests of the community; there is a special permit to run a profession; become a member of a profession. The character of defending the country is a trait that shows a strong spirit that always grows and develops continuously in carrying out every professional activity. The synergy of the ethical component and character of the state defence can be the strength of the accountant's self in creating adequate competence and can become an essential ability or need to form a professional.

Keywords: Ethics, State defence character, Accounting competence, Accountants

\section{INTRODUCTION}




\section{International Journal of Social Science and Economic Research}

ISSN: $2455-8834$

Volume: 05, Issue: 03 "March 2020"

Accounting is a service providing the financial information of an entity at a particular time and period as the basis for decision making. Financial information is the result of the recording process carried out by an accountant that reflects all the operational activities of an entity (Collis et al., 2017). Accounting has a neutral nature, which means providing financial information generated by accounting, what is following the operational conditions of an entity. The neutrality nature of accounting must be considered for misuse by various parties.

Accounting allowance for providing the information is called fraud. Fraud is a distorted problem that can provide benefits or benefits. It can even cause harm or assistance to interested parties (Wahyuni and Gideon, 2017) - related to the application of very complicated accounting for someone or other parties involved (Gideon et al., 2018). The right information will be generated by the right people if there is someone who needs accounting; it will produce financial information that is not right as well. Under these conditions, accounting has been made by certain parties to provide financial information that is not under the actual provisions of the entity (misrepresentation or fraud). To overcome problems involving accounting, that is by considering the competencies of those who use them.

Poerbakawatja (1976) states that ethics is a science that provides direction, reference, and footing for human action. Ethics is the science that investigates excellent and lousy behaviour by observing human actions as far as what is known by the human mind. (Mustafa, 1999). Bertens (1993) states that ethics are moral values and norms that become a reference for human beings individually or in groups in regulating all of their behaviours. Human's behaviour in making decisions related to morals that lead to the use of reason mind with objectivity in order to determine the right or wrong and the behaviour of a person towards others (Spillane, 1992). Salam (2001) states that ethics is a branch of philosophy that discusses the values and norms that can determine human behaviour in his life. Ethics is the science of human behaviour or deeds seen from the good and bad sides of the extent to which it can determine by human reason (Poerwadarminto, 2005). Ethics evolved in all of accounting profession. Accounting academician concern with academic fraud (Aprilisanda, Yuhertiana, \& Priono, 2018; Oktaria Nysa Wardani, 2017). Auditor face the ethical problem on their audit report (Yuhertiana, Patrioty, \& Mohamed, 2019). Ethic appears in all of public budgeting process (Priono, Yuhertiana, Sundari, \& Puspitasari, 2019; Yuhertiana, Moestika S, Hastuti, \& Sundari, 2016; Yuhertiana, Pranoto, \& Priono, 2015)

State defence character is a concept developing patriotism. Physically, interpreted as a defensive effort against physical attacks or aggression from those who threaten the existence of the country, while non-physically this concept interpreted as an effort to play an active role in advancing the nation and state, both through education, morals, social and welfare improvement 


\section{International Journal of Social Science and Economic Research}

ISSN: $2455-8834$

Volume: 05, Issue: 03 "March 2020"

the people who make up the nation. Defending the state and nationalism stick together and become an inseparable unity. The character of the nation needs to be shaped and put forward the interests of the nation and state (Paristiyanti et al., 2016).

Competence is an ability to carry out a job based on skills and knowledge and supported by the work attitude required by the job (Wibowo, 2012; Spencer and Spencer, 1993, Moeheriono, 2010). Besides competence is a fundamental characteristic possessed by an individual who causally related in meeting the criteria needed in occupying a position (Palan, 2007; Zwell, 2000), and in the framework of developing human resources (Surihatiningrum, 2013). Competence is an attribute to attach qualified and superior human resources (Sudarmanto, 2009). There are five dimensions of competency - first, task skills, skills to carry out routine tasks following workplace standards. Second, task management skills, skills to manage a different set of tasks that arise in a job. Third, contingency management skills, skills to take quick and appropriate actions when problems arise at work. Fourth, job role/environment skills, skills to work together and maintain the comfort of the work environment. Fifth, adjustment skill, skill to adapt to the new work environment

\section{METHODOLOGY}

\subsection{Research Design}

This research uses qualitative research with an interpretive approach. To map aspects of accountants' behaviour and character related to Ethics, Defending the Country and Accounting Competencies in a person and the professional community in accounting in depth. This research conducted using meta-analysis, interview and observation techniques in several communities accountants who work as Public Accountants, Tax Accountants, Management Accountants and Educator Accountants, in several cities in Java, including Surabaya, Semarang, Yogyakarta, Bandung, Jakarta. Overall there are nine informants participate in this research.

\subsection{Research Model}

This study seeks to explore the behaviour and charters of accountants to be able to find out some of the characteristics or attributes that reflected in the Accountant Professional community, which can provide information as a specific and unique characteristic.

\subsection{Data Collection}

This study uses primary data obtained directly from data sources. Primary data is data obtained from the first source either from individuals or individuals such as the results of interviews or the results of questionnaires that are usually done by researchers (Umar, 2009: 42). Primary data 


\section{International Journal of Social Science and Economic Research}

ISSN: $2455-8834$

Volume: 05, Issue: 03 "March 2020"

sources in this study came from answers/statements from data sources based on questions given to the Accountants. Data collection technique use in-depth interview techniques. An unstructured interview and observation used to understand the perception of state defence of accounting professions. Resource persons in this study are accountants who work in the field of education, tax and companies. Data obtained from resource persons are not limited to only a few accountants, but rather efforts to find a unique characteristic, which can better reflect the superior character.

The sample used in this study uses the Snowball sampling technique, taking into account equal emphasis on representation in the four fields of work of accountants as Educator Accountants, Tax Accountants, Management Accountants and Educator Accountants until the data is considered sufficient.

\section{RESULT AND DISCUSSION}

\subsection{The role of ethics in the accounting profession.}

Ethical values do not only belong to one or two people, or a group of people but owned by every group of people, even the smallest group, namely the family to a community or even a nation. With these ethical values, a group expected to have a set of values to regulate life together. This group is often the centre of attention because of the existence of a set of values that are set out in written form (i.e. the professional code of ethics) and expected to become a guideline for its members. The negative view of the community becomes more reliable when the behaviours of some members of the profession not based on social values that have been mutually agreed upon (contained in the professional code of ethics) so that there is a decline in ethical values in the professional community.

Ethical views from the viewpoint of accountants educators, even from accountants in general, state that ethics is nothing but the rules of behaviour, human habits in association with each other and affirm what is right and what is wrong. The word ethics or commonly called ethics, which means the norms, values, rules and standards for ethical human behaviour. Ethics in its development dramatically affect human life. Ethics gives people-orientation as to how they live their lives through a series of daily actions. That means ethics help people, including accountants, to take an attitude and act appropriately in living this life, including in carrying out professional activities in the field of accounting.

Ethical judgment focuses on ethics as a science, is on good or evil deeds, immoral or immoral. Concretely the assessment of ethics divided in (a) good intentions, but the way to achieve them is not right; (b) the purpose is not useful, how to achieve it; looks good; (c) the goal is not right, 


\section{International Journal of Social Science and Economic Research}

ISSN: $2455-8834$

Volume: 05, Issue: 03 "March 2020"

and the way to achieve it is also not good; (d) the purpose is useful, and the way to achieve it also looks good.

Accountant's job is a profession that is related to a field that is strongly influenced by education and expertise so that many people who work remain appropriate. To be called a profession is not enough to be fulfilled with the expertise gained from education, but also the need for mastering a systematic theory that underlies the practice of implementation, and the relationship between theory and application in practice. There are several characteristics as professional. (a) the existence of specialized knowledge, which is the expertise and skills possessed thanks to education, training and years of experience; (b) there are very high rules and moral standards. Every professional actor bases his activities on the professional code of ethics; (c) serve the interests of the community, meaning that each professional implementer must place personal interests below the interests of the community; (d) there is a special permit to carry out a profession. Every profession will always be related to the interests of the community, where human values in the form of safety, security and survival so to run a profession must first have a special permit, (e) professionals usually become members of a profession.

Ethics ultimately helps accountants to make decisions about what actions need to taken and which need to understand together that this ethic applied in all aspects of human life. Thus this ethic can be divided into several sections according to aspects of the human side of life.

\subsection{Competence in the accounting profession}

Competence is the ability to carry out something obtained through education and training. As mandated in Law No. 14 of 2005 Article 8, which states educators must have academic qualifications, competencies, academic certificates, physically and mentally healthy, and can realize national education. Specifically, Article 10 Paragraph (1) states that educator competencies include pedagogical competencies, personal competencies, social competencies, and professional competencies obtained through professional education. Indonesia Directorate General of Higher Education defines four (4) educators' competencies mentioned in subcompetencies, competency indicators, essential indicators, and their descriptions in the interests of the preparation of teacher certification instruments.

An educator must understand the background, characteristics, uniqueness, and different abilities. As stated by Benjamin Bloom, there are at least two individual characteristics of students, namely: First, cognitive characteristics related to students' intellectual abilities and the factors that influence them. Second, affective characteristics related to aspects such as interests, motivation, self-concept, and attitudes (towards school, subjects and peers). In addition to the two characteristics above, there are also psychosocial or psychomotor characteristics. 


\section{International Journal of Social Science and Economic Research}

ISSN: $2455-8834$

Volume: 05, Issue: 03 "March 2020"

Educator accountants must master learning theories and principles of learning in educating, which consist of the behaviourism theory, cognitive theory, humanistic-constructivist theory. Behaviourism theory is an early theory in learning that emphasizes the importance of external stimuli to influence learners to learn. The assumption is that students are passive subjects who can only learn if there are certain stimuli from the outside. Educators are central and complementary to learning that observed through its behaviour.

In cognitive theory understanding, learning is a process of processing information that observed. That process occurs in one's mind when obtaining information or stimuli from outside through the five senses. Information received is then processed, filtered, processed, and if meaningful, it will be stored in a temporary storage unit (short term memory) or permanent (long term memory). Information that has stored can be withdrawn and used as needed

Humanistic-constructivist theory, this theory views students who were previously considered as passive subjects to be active subjects. This theory argues that students are subjects who actively create their knowledge, based on experiences with the environment. Because knowledge is not a collection of facts or concepts that information to students, but rather a reconstruction of the experience gained.

Basic concepts of competence an educator is a professional educator with the main task of educating, teaching, guiding, directing, training, evaluating, and evaluating students in early childhood education through formal education, primary education, and secondary education. Competence shows that: 1 . Competence is a set of knowledge, skills and behaviours that must be possessed, internalized, mastered, and actualized by educators in carrying out professional tasks. 2. Competencies include pedagogical competencies, personality competencies, social competencies, and professional competencies obtained through professional education. 3 . Competence is holistic. Requirements in mastering the teaching-learning process and mastery of knowledge, namely: a) Competence of the teaching and learning process, Namely mastery of abilities related to the learning process.

Based on the explanation above, it said that accounting educator must have basic knowledge, especially accounting. Basic knowledge obtained when they attend formal education. It can even obtain through informal education, such as education and training programs from an official institution that has authority from the government or professional institutions. Besides that, educator accountants required to have educator certificates issued by an official institution. In the latest development, the teaching accountant profession can be played by accounting practitioners who certainly have fulfilled some of the required attributes in the academic world, through the process of recognition of equalization by educational institutions. 


\section{International Journal of Social Science and Economic Research}

ISSN: $2455-8834$

Volume: 05, Issue: 03 "March 2020"

\subsection{Accountant perception of state defence character}

Nowadays, reality shows that various physical and non-physical threats in a professional demand to have the spirit of defending the country. The concept of defending the country is not limited to involvement in the military because defending the country can be done by everyone in their respective professions. The concept of national defence has broad dimensions of understanding, including how to be the best in their respective professions, serving according to the profession. A strong defence character is needed so that this nation can face a variety of problems ranging from the profound love of the homeland, radicalism, intolerance, drugs, and unemployment.

Higher education needs to apply the fundamental values of nationalism and national defence both in curricular or extracurricular activities or curriculums. Among these can be realized through the provision of national insight courses by each lecturer, namely: moral and ethical cultivation, conducting seminars, training, and open dialogue, also through student association activities. Higher education institutions in Indonesia have a strategic role in preparing superior human resources because efforts to defend the country made without having superior competence to compete with other countries.

The implementation of state defence character internalized in citizens activities, both physical and non-physical, following their respective capacities and competencies. In this case, the related regulatory support becomes essential in defence of the state, and all related parties need to work together in facing various problems. Something that is not easy to synergize everything. The current reality shows the existence of sectoral ego problems that are still strong in some groups of society both in organizations and institutions. It takes a strong effort, both from within human beings and organizations together.

Based on the explanation above, it said that accountants in Indonesia generally have the competencies required by professional institutions ( Ikatan Akuntan Indonesia). The character of the state defence as explained in theory, they have understood and realized in a variety of ways among several accountants. For accountants who work by prioritizing an independency demand, they have a strong character to maintain their existence to pay attention to the adverse effects caused if an accountant's job not carried out professionally. Accountants like this referred to as Public Accountants. They have a task in the form of a work that puts forward the characteristics that maintain its independence, objectivity, integrity, and competence. They have a strong character to not easily sacrifice themselves only for an individual goal or the interests of other parties (called clients) that are short-term or short-term. They prioritize an unfortunate risk consequence that can occur from a job that is done inadequately or does not comply with professional rules. 


\section{International Journal of Social Science and Economic Research}

ISSN: $2455-8834$

Volume: 05, Issue: 03 "March 2020"

All work has consequences, including risks that must be faced. When someone is carrying out a task or job, then they should already have a competency. The unique or specific a task or job needs specific competencies possessed by its profession. Moreover, all the competencies used to carry out a job controlled by the person carrying out the work. To provide that someone has competence in carrying out specific jobs, needed ethical behaviour. Furthermore, the character formed in a person can provide strong support, that someone has confidence in their competence to carry out a task or job and in a conscious condition for the consequences of risks that can occur if a person does not use his competency responsibly.

The application of competencies carried out by accountants in carrying out their work always puts forward technical expertise and develops and improves themselves through continuing education. Moreover, every time they use their competencies, the accountant must be in a conscious condition that the application of his competence as a consequence, that is, it can bring a result that benefits the parties concerned. From this consequence, professional work such as an accountant controlled by taking into account the professional ethics. With the meaning of the word that the implementation of competence always coincides with ethical awareness. Based on the criteria and characteristics inherent in accountants, it said that the profession carried out by accountants is a job that requires a competency.

Awareness and self-awareness of the risks that occur if someone denies the competence can refer to as the application of ethics. In the final word, there is a synergy between ethics and certain characters (in this case defending the country) that can provide someone support always to pay attention and strive for a competency. While competencies possessed need to be carried out responsibly with full ethical awareness of the profession (of the competencies possessed) and can provide quality work if supported by a strong self-character. The synergy of these three components becomes a unified whole which has a tendency that cannot separate from one another. The implications of this research are; if these three components manifested in a person in carrying out each of his professional work, then a controlled human behaviour can be achieved, which in the end the management of an organization can be free from acts of fraud or corruption (Wahyuni and Gideon, 2017).

\section{CONCLUSION}

There are three findings in this study. First, the accountant is a profession that carries out its work according to scientific ability and extraordinary technical expertise. Second, the accountant profession requires competence as specialized knowledge that requires years of expertise, skills and experience; high moral standards; serve the interests of the community; there is a special permit to run a profession; become a member of a profession. Third, the character of the defence 
International Journal of Social Science and Economic Research

ISSN: $2455-8834$

Volume: 05, Issue: 03 "March 2020"

of the state in various professional spheres is a continuous effort in every activity of citizens who can realize a strong competence in the field of accounting.

It suggested for future research expected to examine the factors of organizational culture and attitudes that shape the accountant's personality in carrying out professional practice. Furthermore, assessing the cheating factor to assess the effectiveness of the three components of ethics, defending the country's character and competence in the accounting profession.

\section{ACKNOWLEDGEMENTS}

This article was funded by Universitas Pembangunan Nasional Veteran Jawa Timur in "Riset Unggulan Keilmuan" grant.

\section{REFERENCES}

Aprilisanda, I. D., Yuhertiana, I., \& Priono, H. (2018). Persepsi Dosen Akuntansi Terhadap Praktik Kecurangan Akademik Pada Upn "Veteran" Jawa Timur (Studi Pada Progdi Akuntansi). Behavioral Accounting Journal. https://doi.org/10.33005/baj.v1i1.21

Barnawi dan Muhammad Arifin. 2012. Etika dan Profesi Kependidikan. Jogjakarta : Ar-Ruzz Media

Bertens, K.1993. Etika, Jakarta: Gramedia.

Collis, J., Holt, A., Hussey, R., Collis, J., Holt, A., \& Hussey, R. 2017. The conceptual framework for financial reporting. In Business Accounting. https://doi.org/10.1057/978$\underline{1-137-52150-7 \quad 5}$

Gideon S.B., Indrawati Y., dan Luqita R. 2018. Good University Governance Oriented of Change Management, Budgeting System, and Behavioural Aspect. $3^{\text {rd }}$ International Seminar of Research Month 2018. Universitas Pembangunan Nasional Veteran Jawa Timur.

Handoyo, Seger. 2010. "Pengukuran Servant Leadership Sebagai Alternatif Assessing Servant Leadership as Leadership Alternative in Higher Education at Organizational Change Era Abstract." Makara, Sosial Humaniora 14 (2): 130-40.

Marselus R. Payong. 2011. Sertifikasi Profesi Pendidik : Konsep Dasar, Problematika dan Implementasinya. Jakarta : PT Indeks

Moeheriono. 2010. Pengukuran Kinerja Berbasis Kompetensi: Competency Based Human Resource Management. Jakarta: Ghalia Indonesia. 
International Journal of Social Science and Economic Research

ISSN: $2455-8834$

Volume: 05, Issue: 03 "March 2020"

Mustofa, H.A. 1999. Akhlak Tasawuf, Bandung: CV. Pustaka Setia.

Oktaria Nysa Wardani, I. Y. 2017. Exploring the courage of accounting students in disclosing fraud. The Indonesian Accounting Review. https://doi.org/10.14414/tiar.v6i1.581

Palan, R. 2008. Competency Management. Jakarta: PPM

Paristiyanti Nurwardani et al. 2016. Pendidikan Kewarganegaraan Untuk Perguruan Tinggi. Dierektorat Jenderal Pembelajaran dan Kemahasiswaan Kementerian Riset, Teknologi, dan Pendidikan Tinggi: Jakarta.

Priono, H., Yuhertiana, I., Sundari, S., \& Puspitasari, D. S. 2019. Role of financial management in the improvement of local government performance. Humanities and Social Sciences Reviews. https://doi.org/10.18510/hssr.2019.7110

Poerbakawatja, Soegarda dan Harahap. 1976. Ensiklopedi Pendidikan, Jakarta : Gunung Agung, Cetakan. III. Edisi II.

Poerwadarminta, W.J.S. 2005. Kamus Umum Bahasa Indonesia. Edisi Ketiga. Jakarta: Balai Pustaka.

Salam, Burhanuddin. 2002. Etika Sosial. Asas Moral Dalam Kehidupan Manusia. Jakarta: Rineka Cipta.

Spencer, Lyle M. dan Spencer, Signe M. 1993. 20 Jenis Kompetensi. http://training.ppsdm.com/ p.1126

Spillane, James J., 1992, Etika Bisnis dan Etika Berbisnis, Kanisius, Yogyakarta.

Sudarmanto. 2009. Kinerja dan Pengembangan Kompetensi SDM, Yogyakarta: Pustaka Pelajar,

Surihatiningrum, Jamil. 2013. Pendidik Profesional : Pedoman Kinerja, Kualifikasi, dan Kompetensi Pendidik. Jogjakarta : Ar-Ruzz Media.

Syaiful Sagala. 2009. Kemampuan Profesional Pendidik dan Tenaga Kependidikan. Bandung : ALFABETA

Wahyuni, Gideon S.B. 2017. Fraud Triangle Sebagai Pendeteksi Kecurangan Laporan Keuangan. Jurnal Akuntansi. Volume XXI. No. 01, Januari : 47-61

Wibowo. 2007. Pengertian Kompetensi. https://www.seputarpengetahuan.co.id/2017/06/15pengertian-kompetensi-menurut-para-ahli-jenis-manfaat-lengkap.html 
Wibowo.2009. Manajemen Kinerja. Jakarta: Rajawali Pers

Yuhertiana, I., Patrioty, C. N., \& Mohamed, N. 2019. The moderating effect of organizational changes on the influence of ethical decision making on public sector internal auditor performance. Contemporary Economics. https://doi.org/10.5709/ce.1897-9254.327

Yuhertiana, I., Moestika S, R., Hastuti, S., \& Sundari, S. 2016. Non Compliance Tax Attitude Is Considered Unacceptable In Small Bussines. Akuntabilitas. https://doi.org/10.15408/akt.v8i2.2765

Yuhertiana, I., Patrioty, C. N., \& Mohamed, N. 2019. The moderating effect of organizational changes on the influence of ethical decision making on public sector internal auditor performance. Contemporary Economics. https://doi.org/10.5709/ce.1897-9254.327

Yuhertiana, I., Pranoto, S., \& Priono, H. 2015. Perilaku disfungsional pada siklus penganggaran pemerintah: Tahap perencanaan anggaran. Jurnal Akuntansi \& Auditing Indonesia. https://doi.org/10.20885/jaai.vol19.iss1.art3

Zwell, Michael. 2000. Creating a Culture of Competence. New York: John Wiley \& Sons, Inc 